Küchel, O., Horky, K., Gregorova, I., and Petrasek, J. (1965). Klinische Wochenschrift, 43, 1318

Lambrew, C. T., Carver, S. T., Peterson, R. E., and Horwith, M. (1961) American fournal of Medicine, 31,81 .

McGiff, J. C., et al. (1970). American fournal of Medicine. 48, 247.

Mellinger, R. C., Petermann, F. L., and Jurgenson, J. C. (1972). fournal of Clinical Endocrinology, 34, 85

Morse, W. J., et al. (1959). American fournal of Medicine, 26, 315

Murphy, B. E. P. (1967). Fournal of Clinical Endocrinology and Metabolism, $27,973$.

Perez, G., Siegel, L., and Schreiner, G. E. (1971). Clinical Research, 19, 543. Perez, G., Siegel, L., and Schreiner, G. E. (1972). Annals of Internal Medicine, 76, 757 .

Posner, J. B., and Jacobs, D. R. (1964). Metabolism, 13, 513.

Rick, W., Winkler, G., Koch, E., and Bohn, H. (1962). Acta Endocrinologica (Kobenhavn), Suppl. No. 67, p. 103.

Schambelan, M., Stockigt, J. R., Collins, R. D., and Biglieri, E. G. (1972). Clinical Research, 20, 220.

Sharma, D. C., Nerenberg, C. A., and Dorfman, R. I. (1967). Biochemistry, 6, 3472 .
Skanse, B., and Hokfelt, B. (1958). Acta Endocrinologica (Kфbenhavn), 28, 29.

Stockigt, R. D., Collins, R. D., Schambelan, M., Brust, N., and Biglieri, E. G. (1971). Clinical Research, 19, 382

Tree, M. (1973). Fournal of Endocrinology, 56, 159.

Tree, M. (1972). Ph.D. Thesis. University of Glasgow.

Ulick, S., et al. (1964). Fournal of Clinical Endocrinology and Metabolism, 24, 669.

Vagnucci, A. H. (1969). Fournal of Clinical Endocrinology and Metabolism, 29, 279.

Vagnucci, A. H. (1970). Nephron, 7, 524.

Visser, H. K. A., and Cost, W. S. (1964). Acta Endocrinologica (Kфbenhavn), $47,589$.

Waite, M. A. (1972a). Fournal of Physiology, 222, 88P.

Waite, M. A. (1973b). Clinical Science. In press.

Weidman, P., et al. (1972). Clinical Research, 20, 249.

Wilson, I. D., and Goetz, F. C. (1964). American fournal of Medicine, 36, 635

Wrong, O., and Davies, H. E. F. (1959). Quarterly fournal of Medicine, 28, 259 .

MEDICAL MEMORANDA

\section{Intravascular Coagulation Complicating Influenza A Virus Infection}

\section{A. M. DAVISON, D. THOMSON, J. S. ROBSON}

\section{British Medical fournal, 1973, 1, 654-655}

Virus infections may produce intravascular coagulation (McKay and Margaretten, 1967). This paper reports two instances, both in young people, in whom infection with influenza $A$ virus resulted in intrarenal fibrin deposition sufficient to produce renal failure. An epidemic of a new strain of influenza (A/Eng/42/72) virus infection may be expected (British Medical fournal, 1972) and we wish to draw attention to this potentially fatal complication.

\section{Case 1}

A healthy girl of 14 developed nausea, anorexia, and giddiness 10 days after her sister had had similar symptoms. Two days later she noticed haematuria and she had a haemoptysis and haematemesis. She was treated with tetracycline and salicylates but two days later was noted to be slightly jaundiced, and was admitted to hospital.

On admission she was pale, slightly jaundiced, and drowsy. Physical examination showed nothing abnormal apart from widely scattered coarse crepitations. Urine analysis showed many red cells and protein. Biochemical and haematological findings are shown in the table. Bacteriological examination of blood, nose swabs, throat swabs, sputum, and midstream urine produced no abnormality.

The day after admission a renal biopsy was performed after a platelet transfusion. Light microscopy showed a diffuse increase in the number of endothelial and mesangial cells with an associated focal acute tubular necrosis. Immunofluorescence showed fibrin/fibrinogen in glomerular capillary walls which in some areas was sufficient to occlude the lumen. No immunoglobulin or complement was detected. \footnotetext{
Department of Pathology, University of Edinburgh, Edinburgh
EH8 9AG

A. M. DAVISON, M.B., M.R.C.P., Research Fellow

D. THOMSON, M.B., M.R.C.PATH., Senior Lecture

Medical Renal Unit, Department of Medicine, The Royal Infirmary, Edinburgh EH3 9YW

J. S. ROBSON, M.D., F.R.C.P., Reader
}

Biochemical and Haematological Findings in the Two Cases Under Study

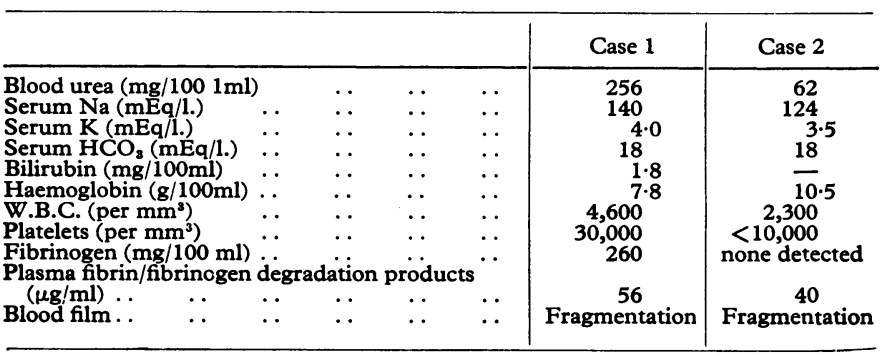

Her blood urea concentration rose to $310 \mathrm{mg} / 100 \mathrm{ml}$ over the next 48 hours and was associated with oliguria. Haemodialysis with a Kolff artificial kidney and an Ultraflo 100 coil under regional heparinization was performed on five occasions, after which there was a satisfactory return to normal renal function. No therapy and in particular no antibiotics or anticoagulants were given.

The abnormal haematological indices returned to normal. Complement fixing antibody titre to influenza $A$ virus rose from $1 / 16$ to $1 / 256$ three weeks later. A repeat biopsy showed resolution of the renal lesions and immunofluorescence showed the presence of small amounts of fibrin/fibrinogen within a few glomerular capillary walls.

Twenty-five days after admission the patient was discharged and remained well.

\section{Case 2}

The second patient, a 14-year-old boy, developed an upper respiratory tract infection and vague muscular pains. He was treated with ampicillin but four days later his symptoms had not improved, he became pyrexial and dyspnoeic, and was admitted to hospital. After admission his dyspnoea became more severe, he became cyanosed, and died from a massive haemoptysis before artificial ventilation could be instituted. Biochemical and haematological investigations are shown in the table. Tracheal secretions produced a scanty growth of Staphylococcus aureus; blood culture was negative.

At necropsy fluid blood was found in the nasal, oral, and respiratory passages and both lungs showed intense haemorrhagic congestion. Petechial haemorrhages were present in the cerebral white matter but other organs showed only congestion.

Influenza $\mathrm{A}$ virus was identified by culture from tracheal and lung tissue. Lung histology showed widespread haemorrhagic destruction of parenchyma and ulceration of the respiratory mucosa. Renal histology showed granular material suggestive of fibrin within glomerular capillaries. There was a slight increase in mesangial cells, and denuded endothelial cell nuclei characteristic of intravascular coagulation (Brown et al., 1969) were seen lying free 
in capillary lumina. Fibrin/fibrinogen was detected by immunofluorescence within glomerular and peritubular capillaries.

\section{Comment}

The two patients were previously healthy young people who developed a 'flu-like illness during a minor epidemic of influenza A. Influenza A virus was implicated in case 1 by serological studies and in case 2 by isolation. In both there was clinical and laboratory evidence of intravascular coagulation. In the first case this produced acute renal failure while in the second a severe consumption coagulopathy produced defibrination, intrapulmonary haemorrhage, and death.

Infectious agents are known to produce intravascular coagulation (McKay and Margaretten, 1967; Dodsworth and Burns, 1971) but influenza A virus has not been implicated previously. Wilson and Smith (1972) reported a case of Goodpasture's syndrome after influenza A2 virus infection but made no mention of intravascular coagulation. The mechanisms whereby viruses induce intravascular coagulation are unknown, but may be related to haemagglutinating properties, haemolytic factors, direct endothelial cell damage, or antigen antibody reactions. In neither of the above cases were we able to detect viral antigen or any significant immunoglobulin deposition within renal tissue. Certain drugs may produce intravascular coagulation in sensitized people but such a mechanism is improbable in these two patients.

The treatment of intravascular coagulation is controversial but the use of anticoagulants has been advocated (Lo et al., 1971). Such drugs are not without hazard, and the first patient resolved satisfactorily without such agents. Anticoagulant therapy should possibly be reserved for those patients with a consumption coagulopathy severe enough to render them at risk from haemorrhage. Such therapy might have been of value in the second patient.

We are grateful to Dr. D. M. F. Batty, consultant physician at the Edinburgh Royal Infirmary, for his kind permission to report details of case 2, and to Dr. A. G. Dempster, of the Regional Virus Laboratory, City Hospital, Edinburgh, for the virological studies.

\section{References}

British Medical fournal, 1972, 4, 251.

Brown, L. J., Stalker, A. L., and Hall, J. (1969). Microvascular Research, $1,295$.

Dodsworth, H., and Burns, A. (1971). British Medical fournal, 4, 466.

Lo, S. S., Hitzig, W. M., and Frick, P. G. (1971). Acta Haematologica, 45, 1 McKay, D. G., and Margaretten, W. (1967). Archives of Internal Medicine, $120,129$.

Wilson, C. B., and Smith, R. C. (1972). Annals of Internal Medicine, 76, 91

\section{Active Chronic Hepatitis after Chlorpromazine Ingestion}

\author{
R. I. RUSSELL, J. G. ALLAN, R. PATRICK
}

British Medical fournal, 1973, 1, 655-656

Active chronic hepatitis, described by Waldenstrom (1950) and Mackay et al. (1956), was initially thought to be a complication of acute viral hepatitis. In about $25 \%$ of patients the condition seems to have been preceded by a classical attack of viral hepatitis (Sherlock, 1968). There is much evidence that active chronic hepatitis is an autoimmune disturbance at the stage of hepatic involvement. Thus, lupus erythematosus cells are found in $15 \%$ of patients, and many patients are found to have false-positive Wassermann reactions, positive R.A. latex tests, and antinuclear and smooth muscle antibodies are found in over 50\% (Johnson et al., 1965; Whittingham et al., 1966). The diagnosis is confirmed by hepatic biopsy, which shows a persistent and often progressive chronic inflammatory reaction in the portal tracts with extension of the cellular exudate into the surrounding periportal tissue. Here the limiting plate of hepatocytes disappears, while small foci of peripheral hepatocyte necrosis (piecemeal necrosis) may be seen. The inflammatory infiltrate consists mainly of lymphocytes and plasma cells, and fibrosis is often conspicuous in the periportal areas and around proliferating bile ductules.

It seems probable that any factor which might cause hepatic damage may precipitate a self-perpetuating destructive process in the liver in the susceptible patient. The virus of viral hepatitis may be responsible in some instances, but other factors might be involved. It is possible that drug-induced hepatic damage may be one such factor. Active chronic hepatitis has recently been Departments of Gastroenterology and Pathology, Royal Infirmary,
Glasgow G4 OSF

R. I. RUSSELL, M.D., F.R.C.P., Consultant Gastroenterologist

J. G. ALLAN, M.B., M.R.C.P., Senior Registrar in Gastroenterology

R. PATRICK, M.D., M.R.C.PATH., Professor in Pathology reported after the prolonged ingestion of laxative preparations containing oxyphenisatin (Reynolds et al., 1971). Histological changes of active chronic hepatitis have also been reported in two patients treated with methyldopa (Morin et al., 1964; Williams and Khan, 1967).

We report a patient who developed active chronic hepatitis after the ingestion of chlorpromazine.

\section{Case Report}

A 59-year-old joiner was admitted to hospital with a three-week history of pruritus, painless jaundice, pale stools, and dark urine. He had a long-standing history of peptic ulceration for which a partial gastrectomy had been performed eight years previously. Six weeks before admission he had had contact with a relative who was jaundiced but who was shortly thereafter found to have carcinoma of the pancreas. He had previously suffered from depression, and this recurred, culminating in his taking an overdosage of aspirin and chlorpromazine four weeks before his admission to hospital. He had not taken other drugs at this time or for some months previously. His alcohol intake was negligible and had not changed for some years.

On admission he was icteric, and the liver was palpable $5 \mathrm{~cm}$ below the costal margin. Investigations, which suggested an obstructive jaundice, were: $\mathrm{Hb} 15.0 \mathrm{~g} / 100 \mathrm{ml}$; E.S.R. $29 \mathrm{~mm}$ in the first hour; bilirubin $9.0 \mathrm{mg} / 100 \mathrm{ml}$; SGOT 31 units/1., SGPT 30 units/1.; alkaline phosphatase $164 \mathrm{~K}$.A. units. The serum albumin was $4.6 \mathrm{~g} / 100 \mathrm{ml}$ and globulin $2 \cdot 7 \mathrm{~g} / 100 \mathrm{ml}$. Protein electrophoresis and immunoglobulins were normal. Bile but no urobilinogen was present in the urine. Alkaline phosphatase isoenzyme studies suggested an increase in both liver and bone constituents. Skeletal survey showed changes consistent with Paget's disease. The hepatitis-associated antigen test was negative, as also was the smooth muscle and antimitochondrial antibody tests. Lupus erythematosus cell test and antinuclear factor were not performed at this time.

The liver biopsy showed evidence of cholestatic jaundice, the centrilobular bile canaliculi being distended with bile plugs (fig. 1). There was some infiltration with inflammatory cells including eosinophils in the portal areas. There was no evidence of hepatocyte necrosis and no fibrosis. The interlobular bile ducts appeared to be normal, although extrahepatic obstruction could not be fully excluded. An exploratory laparotomy was undertaken and no appreciable abnormality was found. A wedge biopsy of liver was taken at operation, and showed only the features which had been noted in the original small needle biopsy (fig. 2). Accordingly, it was thought that the cholestasis and mild portal hepatitis were consistent with the diagnosis of chlorpromazine poisoning. 